\title{
Seroprevalence for equine infectious anaemia in Equidae seized in the municipality of Petrópolis, State of Rio de Janeiro, Brazil, 2015/2018
}

\author{
Astrid Paola Mattheis Cruz ${ }^{1,2}$ (i) Maria Helena Consedey de Aquino ${ }^{1}$ (D) \\ Michel José Sales Abdalla Helayael ${ }^{4}$ Márcio Roberto Silva $^{3}$ Jo João Batista Ribeiro $^{3(D)}$ \\ Marcos Cicarini Hott ${ }^{3} \mathbb{D}$ Walter Coelho Pereira de Magalhães Júnior $^{3}$ (D) \\ Juliana França Monteiro de Mendonça1 ${ }^{1}$ Guilherme Nunes de Souza ${ }^{3,4^{*}}$ (D)
}

\begin{abstract}
${ }^{1}$ Programa de Pós-graduação em Higiene Veterinária e Processamento Tecnológico de Produtos de Origem Animal, Universidade Federal Fluminense (UFF), Niterói, RJ, Brasil.

${ }^{2}$ Serviço Veterinário Oficial do Estado do Rio de Janeiro, Niterói, RJ, Brasil.

${ }^{3}$ Embrapa Gado de Leite, 36038-330, Juiz de Fora, MG, Brazil. E-mail: guilherme.souza@embrapa.br; gnsouza@id.uff.br. "Corresponding author. ${ }^{4}$ Programa de Pós-graduação em Clínica e Reprodução Animal, Universidade Federal Fluminense (UFF), Niterói, RJ, Brasil.

ABSTRACT: Equine infectious anaemia (EIA) is a globally distributed disease caused by a lentivirus. EIA is a notifiable disease that should be reported to the Official Veterinary Service (SVO). Outbreaks are controlled by sacrificing the EIA-positive animals. The study analysed the prevalence of EIA in 165 Equidae seized on public roads in the municipality of Petrópolis, Rio de Janeiro, Brazil, from 2015 to 2018. After the seizure and identification of the Equidae, blood was collected to diagnose EIA. A prevalence of 11.8\% was observed among the Equidae seized, and the main risk factor was the region of seizure. A kernel-smoothed map showed areas with the highest density of EIA-positive Equidae in the centre and to the east of the study area. In this region, the chance of seizing an equine positive for EIA was greater (OR=3.6) relative to the remaining region. The implementation and maintenance of Equidae seizures and subsequent diagnostic testing for EIA in the municipality of Petrópolis were shown to have great importance for the control and prevention of the disease. Indicating the place of seizure on the identification cards of the animals enabled delineation of the locations in the municipality of Petrópolis, that had a higher risk of EIApositive animals.

Key words: Equine, spatial distribution, infectious diseases.
\end{abstract}

Soroprevalência para anemia infecciosa equina em Equídeos apreendidos no município de Petrópolis, RJ, Brasil, 2015/2018

RESUMO: A anemia infecciosa equina (AIE) é uma doença globalmente distribuída causada por um lentivirus. AIE é uma doença de notificação obrigatória que deve ser relatada ao Serviço Veterinário Oficial (SVO), e os surtos são controlados pelo sacrificio dos animais positivos para AIE. O presente estudo analisou a prevalência de AIE em 165 equídeos apreendidos em vias públicas no município de Petrópolis, estado do Rio de Janeiro, Brasil, no periodo de 2015 a 2018. Após a apreensão e identificação dos equídeos seu sangue foi coletado para diagnosticar a AIE. Observou-se uma prevalência real de 11,8\% entre os equídeos apreendidos, sendo que o principal fator de risco identificado foi a região de apreensão. O Mapa de Kernel mostrou que as áreas com maior densidade de equídeos positivos estavam no centro e leste da área de estudo. Nesta região, houve maior chance $(O R=3,6)$ de apreender um animal positivo para AIE em relação ao da outra região, composto pelos 34 locais restantes. A implementação e manutenção de apreensão de equídeos e posterior teste de diagnóstico para AIE no município de Petrópolis, RJ, mostrou-se de grande importância para o controle e prevenção da doença. A indicação do local da apreensão nos cartões de identificação dos animais possibilitou um delineamento dos locais no municipio de Petrópolis, RJ, que apresentavam maior risco de animais positivos para AIE.

Palavras-chave: Equino, distribuição espacial, doenças infecciosas.

Equine infectious anaemia (EIA) is a globally distributed disease and is one of the main infectious diseases that negatively affect the Brazilian equine breeding activity. This disease causes much damage, since, in most of the Brazilian territories, animals positive for EIA are mandatorily sacrificed, according to National Equine Health Program (Brasil, 2004).

The distribution of the virus in Brazil varies substantially among the states and regions.
Some regions have low levels of infection, such as Rio Grande do Sul, but others have higher levels, such as the west-central and northern regions (REBELATTO et al., 1992; ALMEIDA et al., 2006). The prevalence of EIA does not only vary depending on the region or state but also varies according to the animal's main activity and the occurrence of illegal transport (ALMEIDA et al., 2017; MORAESs et al., 2017; BARZONI et al., 2018). Due to this fact, there 
is a wide variation in the prevalence of EIA in Brazil according to the populations studied, with variations ranging from $0.43 \%$ to $46.26 \%$ (FREITAS et al., 2015; BAPTISTA et al., 2016).

The EIA control and prevention measures adopted by the Official Veterinary Service of Rio de Janeiro (SVORJ; Portuguese initials) include the supervision of the seizure of Equidae that do not have owners from along public roads, screening them for EIA, and sacrificing the EIA-positive animals. The objective of this study was to evaluate the seroprevalence of EIA among Equidae seized on public roads in Petrópolis, Rio de Janeiro State, as well as the temporal and spatial distribution of seropositive animals, between January 2015 and March 2018.

One hundred sixty-eight Equidae (horses, donkeys and mules) were seized on the public roads of the municipality of Petrópolis without the presence of owner, state of Rio de Janeiro (RJ), Brazil, from January 2015 to March 2018. After seizure, 165 animals were housed in a seizure corral belonging to the Petropolis city hall, where they underwent identification procedures and EIA screening. The information obtained from animals includes date of seizure, sex, coat, place of seizure. Equidae with negative tests were retrieved by the owner or were donated.

Blood samples for EIA screening were collected for diagnosis was made through agar gel immunodiffusion (AGID) (BRASIL, 2004). The seroprevalence and its respective 95\% confidence interval $(95 \% \mathrm{CI})$ were calculated according to PFEIFFER (2010).

Kernel smoothing was used to map the density of EIA-positive equines and a kernel ratio map. A bandwidth of $5 \mathrm{~km}$ and an output cell size of $50 \mathrm{~m}$ were used to create all kernel-smoothed maps. The map was produced in ArcGIS 9.3 (ESRI, Redlands, CA, USA). The estimation of the risk for EIA and the strategy for constructing the final logistic regression model were determined as described FRANKENA \& GRAAT (1997). In logistic regression model, the dependent variable was the AGID results and independent variable were sex, year, season and place of seizure of the animal obtained from the identification form for the animals.

Results of the variable that referred to the place of seizure of the Equidae were classified into two categories based on the proximity between the places of seizure and the number of animals seized. Accordingly, two regions were identified, the first one comprising the Correas, Itaipava, Nogueira,
Bonsucesso and Madame Machado neighbourhoods (Region 1). The second region comprised the other locations or neighbourhoods indicated on the identification form for the animals (Araras, Barão do Rio Branco, Benfica, Carangola, Cascatinha, Caxambu, Centro, Chácara das Rosas, Coronel Veiga, Fragoso, Frias, Jardim Salvador, Laginha, Lopes Trovão, Pedro do Rio, Praça da Liberdade, Quarteirão Brasileiro, Quitandinha, Retiro, Roseiral, Santa Mônica, São Sebastião, Secretário, Thouzet, Vale da Lua, Vale das Videiras, Vale do Cuiabá, Vale dos Esquilos, Vicenzo Rivetti and Vila Felipe) (Region 2 ). The time of year was categorized according to the month when the Equidae were seized, and the months of November, December, January, February, March and April were considered the rainy season, whereas the months of May, June, July, August, September and October were considered the dry season.

During the study period, 165 Equidae were seized in 39 different places (neighbourhoods or locations not designated as neighbourhoods) in Petrópolis, RJ. Of the Equidae seized, identification and EIA screening were performed for 165 (97.0\%). Regarding the sex of the Equidae seized, 57 (34.5\%) were females, and $108(65.5 \%)$ were males. The number of animals seized over the years showed that the largest number of Equidae (72/42.6\%) were seized in 2015 , followed by a reduction in $2016(37 / 21.9 \%)$ and an increase in 2017 (42/24.9\%); in 2018, 18 (10.7\%) Equidae had been seized and identified until March. Regarding the time of year, 94 (55.6\%) and $75(44.4 \%)$ Equidae were seized in the rainy and dry periods, respectively.

The Nogueira location had the highest number of Equidae seized (38/22.6\%), followed by Carangola (14/8.3\%), Bonsucesso (10/6.0\%), Barão do Rio Branco (9/5.4\%) and Correas (9/5.4\%). In Regions 1 and 2, respectively, 67 (39.9\%) and 101 $(60.1 \%)$ Equidae were seized. However, Regions 1 and 2 comprised $5(12.5 \%)$ and $35(87.5 \%)$, respectively, of the total locations identified in Petrópolis, RJ. The prevalence $(11,5 \%)$ of EIA among the Equidae were considered high, with a $95 \%$ confidence interval ranging from $6.6 \%$ to $16.4 \%$. A kernel-smoothed map showed areas with the highest density of EIApositive Equidae present were in the centre and east of the study area (Figure 1), whereas the kernel ratio map identified a more extensive high-risk area in the centre of the region, together with small areas in the east and northern regions of the study area.

The associations between the serological results and the information obtained from the individual animals showed statistical significance for 


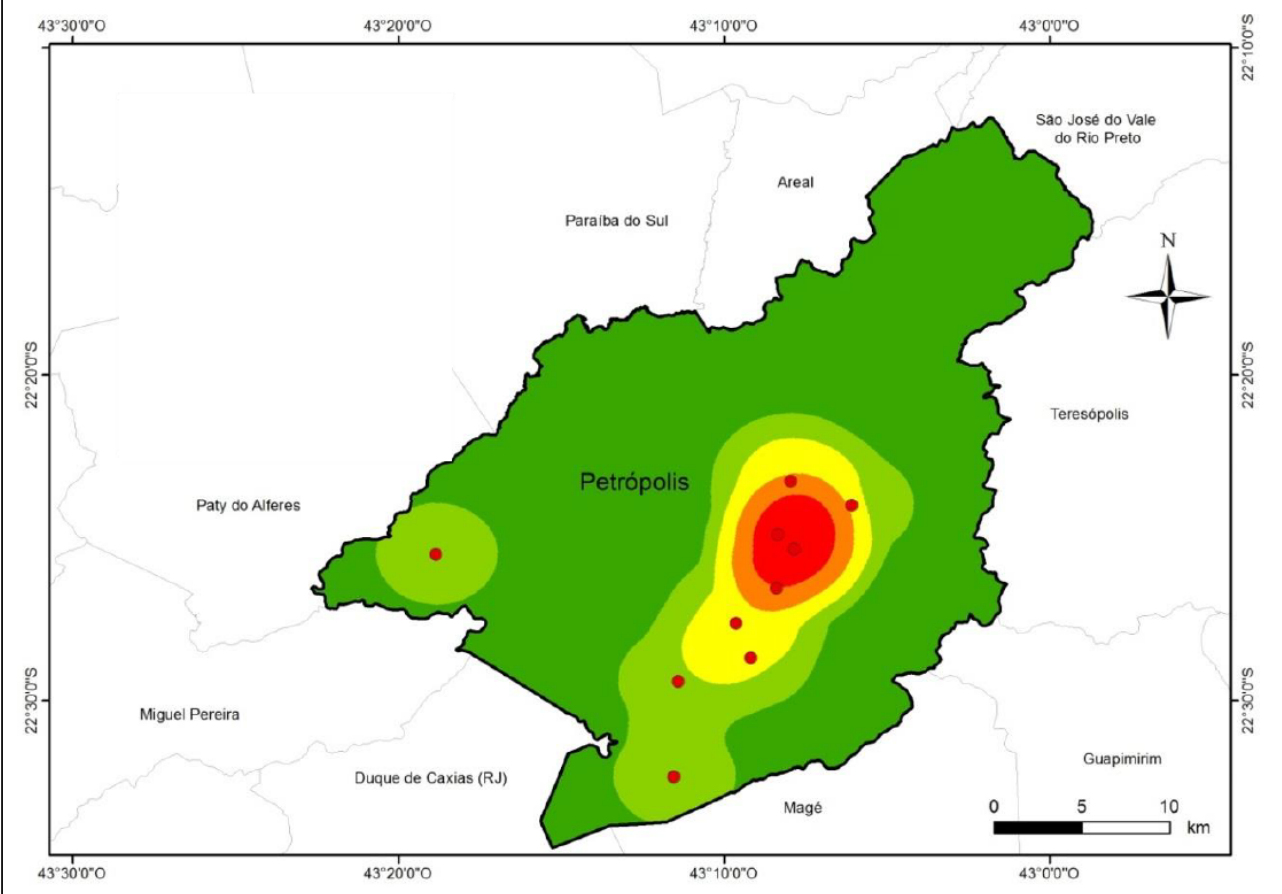

Figure 1 - Kernel smoothed intensity of Equidae positive equine infectious anaemia (EIA) in Petrópolis municipality, RJ, Brazil, 2015 to 2018 ( $5 \mathrm{Km}$ bandwidth, $50 \mathrm{~m}$ grid cells).

the place of seizure $(\mathrm{P}<0.05)$. Based on the results of the univariate analyses between the results of the serological tests for EIA and the information obtained from the individual animals, the variables sex and place of seizure were evaluated together in the final logistic regression model. The logistic regression model presented statistical significance $(\mathrm{P}<0.01$, $\mathrm{R}^{2}=0.119$ ). The only variable identified as a risk factor was the place of seizure, specifically Region $1(\mathrm{OR}=3.6)$. Results showed that the place of seizure of the Equidae was the main risk factor for EIA, specifically Region 1, which comprised the localities/ neighbourhoods of Correas, Itaipava, Nogueira, Bonsucesso and Madame Machado. Although, this region represented $12.5 \%$ of the locations, $68.4 \%$ (13/19) of positive animals was observed in this region. Conversely, region 2 , which comprised the remaining 34 localities/neighbourhoods, accounted for $87.5 \%$ of the locations identified in the municipality and $31.6 \%$ $(6 / 19)$ of the positive animals. This information, relating the association of a higher prevalence with a certain region of a municipality or state, can be crucial for decision making regarding the control, prevention and eradication of the disease and for the maintenance of epidemiological surveillance activities.

Seizing Equidae, that were roaming, and without owners from the public roads of Petrópolis, $\mathrm{RJ}$, enabled an evaluation of the epidemiological situation of EIA in this specific population of Equidae. Generally, these Equidae have owners, but these owners might not have had adequate feeding, space or fencing conditions, and for these reasons, Equidae often end up escaping or being released onto public roads. The screening of Equidae for EIA is mostly performed for transit purposes, as a negative test is mandatory for the issuance of the GTA. However, the irregular and illegal movement and trade of these animals occurs.

According to BAPTISTA et al. (2016), EIA is endemic in the state of Rio de Janeiro, with occurrences in all regions of the state. According to a survey conducted from 2007 to 2011, the observed prevalence was approximately $0.5 \%$, which is considered low. However, the study did not show the real prevalence for the state because data from the laboratories that performed serological tests for GTA 
were used, which mostly corresponds to animals that needed the GTA for transportation. The estimated prevalence in the study was twenty times higher compared to the study by BAPTISTA et al. (2016) in the state of Rio de Janeiro.

A study carried out in the state of Minas Gerais showed a higher prevalence $(14.9 \%)$ and; consequently, a higher risk for EIA in the north/northwestern region of Minas Gerais compared to the westcentral region of Minas Gerais and the metropolitan area of Belo Horizonte (1.4\%) (Almeida et al., 2006). Despite differences in the characteristics of the Equidae population between the study by ALMEIDA et al. (2006) and the present study, as well as in the size of a municipality relative to a state, a variation in prevalence was observed across areas in both studies.

However, MORAES et al. (2017) conducted a study on working Equidae in the Federal District and found a prevalence of $1.81 \%$. Although, the prevalence in the present study was 6 times higher than that observed by MORAES et al. (2017), we emphasized that the animals seized in this study were not seized as roaming animals. Nevertheless, they were in a similar situation as those in the present study; that is, they were traversing the streets and without constant screenings despite having owners, approximately $80 \%$ of whom declared having knowledge of EIA. Results of the studies carried out in the Federal District, Minas Gerais and Rio de Janeiro showed that the epidemiological situation of the disease differed according to the location (state) and function (working or sports/leisure animals) of the studied Equidae population.

After seizure of the Equidae and completion of the individual information, the identification of the place of seizure was possible. This information enabled the identification of the locations and/or neighbourhoods of Petrópolis where the highest number of seizures occurred. This could be strategic information to support localized actions and campaigns to increase the awareness of the population and the owners of the risks of accidents and the dissemination of diseases that can occur as a result of animals being loose on public roads. Among the farmers of Petrópolis, especially among horse owners, irregular and illegal trade of animals is well known to occur between the Teresópolis and Petrópolis municipalities. Finally, it is important to note that these horses released on public roads, regardless of the reason, and that are not submitted to veterinary assistance can contribute to the maintenance of the agent and consequently influence the health status in the region. Due to the official veterinary service from state has no management over seized animals at the level of municipality, the study showed an important partnership path between the state and municipal official veterinary service focused on disease control and prevention.

The implementation and maintenance of Equidae seizures and subsequent EIA screening in the municipality of Petrópolis, RJ, have proven to be important for the control and prevention of EIA in Petrópolis due to the identification and removal of infected animal from public roads. The prevalence of $11.8 \%$ for EIA was considered high. The prevalence of EIA among Equidae seized did not vary according to the year. The identification of the place of seizure on the identification form for the animals enabled delineation of the locations in Petrópolis, RJ, that are at a higher risk of EIA-positive animals.

\section{ACKNOWLEDGEMENTS}

The authors would like to thank the Serviço Veterinário Oficial do Estado do Rio de Janeiro, Programa de Pós Graduação em Medicina Veterinária da Universidade Federal Fluminense (UFF) e Embrapa Gado de Leite for the partnership that made this study possible.

\section{BIOETHICS AND BIOSSECURITY COMMITTEE APPROVAL}

We authors of the article entitled "Seroprevalence for equine infectious anaemia in Equidae seized in the municipality of Petrópolis, State of Rio de Janeiro, Brazil, 2015/2018” declared, for all due purposes, the project that gave rise to the present data of the same has not been submitted for evaluation to the Ethics Committee of the University, but we are aware of the content of the Brazilian resolutions of the National Council for Control of Animal Experimentation - CONCEA "http://www. met.gov.br/ index.php/content/view/310553.html" if it involves animals." Thus, the authors assume full responsibility for the presented data and are available for possible questions, should they be required by the competent authorities.

\section{DECLARATION OF CONFLICT OF INTEREST}

The authors declare no conflict of interest. The founding sponsors had no role in the design of the study; in the collection, analyses, or interpretation of data; in the writing of the manuscript; or in the decision to publish the results.

\section{AUTHORS' CONTRIBUTIONS}

The authors contributed equally to the manuscript.

\section{REFERENCES}

ALMEIDA, V.M.A., et al. Anemia infecciosa equina: prevalência em equídeos de serviço em Minas Gerais. Arquivo Brasileiro

Ciência Rural, v.50, n.4, 2020. 
de Medicina Veterinária e Zootecnia, v.58, n.2, p.141148, 2006. Available from: <https://doi.org/10.1590/S010209352006000200001>. Accessed: Jan. 15, 2019. doi: 10.1590/ S0102-09352006000200001.

ALMEIDA, V.M.A., et al. Gonçalves, V.S.P. Prevalência da anemia infecciosa equina em haras de Minas Gerais, Brasil. Semina: Ciência Agrária, v.38, n.3, p.1335-1346, 2017. Available from: <https://doi.org/10.5433/1679-0359.2017v38n3p1335>.Accessed: Mar. 20, 2019. doi: 10.5433/1679-0359.2017v38n3p1335.

BAPTISTA, D.Q. et al, 2016. Temporal series analyses in equine infectious anemia cases in the State of Rio de Janeiro, Brazil, 2007 to 2011. Revista Brasileira de Medicina Veterinária, v.38, n.4, 431-438, 2016. Available from: <http://rbmv.org/index.php/ BJVM/article/view/134>. Accessed: Mar. 20, 2019.

BARZONI, C. S., et al. Equine infectious anemia in the western region of Rio Grande do Sul, Brazil. Ciência Rural. v.48, n.6, p.e20170809, 2018. Available from: $<$ https://doi.org/10.1590/01038478cr20170809>. Accessed: Jul. 07, 2019. doi: 10.1590/0103$8478 \mathrm{cr} 20170809$.

BRASIL. Instrução Normativa n. 45, de 15 de junho de 2004 Aprova as normas para a Prevenção e o Controle da Anemia Infecciosa Equina - AIE. Diário Oficial [da] União, Brasília, DF, seção 1, p. 7.
FRANKENA, K.; GRAAT, E.A.M., Multivariate analysis: logistic regression. In: Noordhuizen, J.P.T.M.; Frankena, K.; Van der Hoofd, C.M.; Application of quantitative methods in veterinary epidemiology. First ed. Wageningen: Wageningen Pers, p. 135$178,1997$.

FREITAS, N.F.Q.R., et al. Equine infectious anemia on Marajo Island at the mouth of the Amazon river. Pesquisa Veterinária Brasileira, v.35, n.12, p.947-950, 2015. Available from: <https:// doi.org/10.1590/S0100-736X2015001200002>. Accessed: Jan. 27, 2019. doi: 10.1590/S0100-736X2015001200002.

MORAES, D.D.A., et al. Situação epidemiológica da anemia infecciosa equina em equídeos de tração do Distrito Federal. Pesquisa Veterinária Brasileira, v.37, n.10, p.1074-1078, 2017. Available from: $\quad<$ https://doi.org/10.1590/s0100-736x2017001000006>. Accessed: mai. 16, 2019. doi: 10.1590/s0100-736x2017001000006.

PFEIFFER, D.U. Veterinary epidemiology: an introduction. First ed. Wiley-Blackwell, Ames, 2010.

REBELATTO, M.C., et al. Serological diagnosis of equine infectious anaemia virus infection in the central region of the Rio Grande do Sul state. Ciência Rural, v.22, n.2, 179196, 1992. Available from: <https://doi.org/10.1590/S010384781992000200012>. Accessed: Feb. 20, 2019. doi: 10.1590/ S0103-84781992000200012. 